Article

\title{
Factor Affecting Attitude and Purchase Intention of Luxury Fashion Product Consumption: A Case of Korean University Students
}

\author{
Maidul Islam ${ }^{1, *}$ and Bidhanchandra Nahakpam Singh ${ }^{2}$ (]) \\ 1 Department of E-Trade, Keimyung University, Daegu 42601, Korea \\ 2 Department of Distribution Management, Tongmyong University, Busan 48520, Korea; nahakpam@tu.ac.kr \\ * Correspondence: maidul@kmu.ac.kr; Tel.: +82-53-580-5967
}

Received: 21 July 2020; Accepted: 8 September 2020; Published: 11 September 2020

check for updates

\begin{abstract}
The purpose of this study was to look into the factors affecting South Korean college students' luxury goods purchases and their intent to buy them. A conceptual model was proposed and was tested by several hypotheses. Data were collected from Seoul, Daegu, and Daejeon in South Korea. A total of 153 respondents took part in this survey, which was conducted on brand awareness, social contrast, acquisitive, innovation in fashion, engagement in fashion, buying luxury brand attitudes, and buying interest of luxury products. Factor analysis and regression analysis were done to test the hypotheses by using SPSS. The results of this study indicated a significant positive relationship between the buying intention of luxury products and brand awareness, social contrast, and innovation in fashion. This paper help manufacturer and marketing managers to make better marketing strategies for college students.
\end{abstract}

Keywords: luxury fashion goods; social comparison; shopping enjoyment; fashion lifestyle university students; brand awareness

\section{Introduction}

South Korea has the fourth-largest GDP in Asia and the 12th largest in the world. South Korea is known for its rapid growth from one of the poorest countries in the world to a high-income country in a short period of time [1]. Due to the economic growth of South Korea, it is expected that people's perception of luxury products will change. After almost completely opening its markets to the globe in compliance with the International Monetary Fund guidelines in 1997, Korean consumers have been rapidly becoming global consumers developing tastes similar to those in the developed Western countries. The rapid recovery of the economy from the 1997 foreign exchange crisis has boosted demands for foreign products, especially in the luxury market, which led to a drastic increase in purchasing powers. As such, they are enjoying a greater variety of products at cheaper prices since Korea's import liberalization ratio reached 99 percent in 1997 [2], which made Koreans familiar with foreign brand names and products, especially in the area of fashion, while young consumers who are far more fashion-conscious than the older and more frugal generations are rapidly picking up the globalized consumption [3]. Buying luxury products was considered to be the sole property of the upper class, in all the age groups. According to the Korean central bank, there is a rising purchase of foreign luxury products, and it is being pointed out that, in the first month of $2002,19.5 \%$ of household spending on goods went to imported products [4]. If we simply look into the luxury bag market, the size of South Korea's luxury bag market was estimated at about 3.23 trillion won last year, according to market researcher Euromonitor. It is the fourth-largest in the world after the United States, China, and Japan. The market for luxury goods in Korea amounted to $\$ 12.23$ billion 
(13.2932 trillion KRW) last year. It is the world's eighth-largest after the United States, Japan, China, France, Italy, Britain, and Germany, and is the third-largest in Asia (Asia Economic, 2019). The trend of preferring and purchasing luxury goods is spreading like a syndrome in the wake of the wave of globalization and openness. The consumer class of luxury goods-formerly the main customers were high-income people in their 30s and 40s-is now commonly those in their $20 \mathrm{~s}$, college students, and high school students [5]. People in their 20s in particular are emerging as a leading age group that expands consumption as a generation that grew up amid material affluence. In addition, from a socio-psychological point of view, they have a strong desire to own luxury goods through social contrast pursuit, control, and self-efficiency, and are leading the trend of luxury consumption and emerging as the main customers of luxury stores despite lower income levels than older people [6]. College students now maintain a fairly high level of consumption compared to college students in the past. They are buying luxury goods not only through existing department stores and duty-free shops but also through various routes such as online shopping malls and overseas direct pitches. As the purchase and interest of luxury goods by college students grows, there is a need for research to be conducted on a group of college students who are increasingly becoming the main consumers. Therefore, the purpose of this study was to identify the factors affecting university students' attitudes toward the purchase of luxury products and to investigate the impact of consumers' attitudes and buying intention on luxury products.

\section{Literature Review}

There has been an immense interest among researchers to study the luxury markets due to its growth in the recent past. The size of the luxury market reached more than 1 trillion USD in 2014, and it consists of a number of diverse categories [7]. This market has also experienced enormous growth, with the total number of consumers in the past twenty years tripling, and is predicted to reach 400 luxury consumers worldwide by 2020 [8]. One of the main factors for this global phenomenon has been attributed to the increase in luxury consumption in many Asian markets. Moreover, fierce demand in the emerging markets of India, China, and the Middle East has fueled much of the growth of the overall luxury market in recent years [9].

There is not a widely accepted definition of what constitutes a luxury brand. For example, there is no term in the American Marketing Association's dictionary that defines "luxury," "luxury brand," or "luxury marketing." However, scholars from different disciplines have attempted to define what constitutes a luxury brand but without a clear consensus. Although some semiotics scholars have argued that there are certain "codes of luxury" that are consistent across disciplines and ages [10], and there are a number of challenges in composing a definition of luxury brands, including the fact that luxury is a relative concept [11], and that perceptions of what constitutes "luxury" have changed over time [12]. These and other challenges have led [13] to state that prior research is characterized by "... a lack of clarity regarding a definition, operationalization, and measurement of brand luxury." This observation is consistent with previous calls by researchers for a more precise definition of luxury goods marketing [14]. It has further been claimed that the definition and measurement of luxury have been highly subjective even though luxury is not an inherently subjective construct [15]. Thus, it remains possible and desirable to define what a luxury brand is and measure the degree to which a given brand is a luxury brand.

Luxury fashion products are often expressed as superior goods, sophisticated, and elegant in style [16]. Several authors defined luxury products as goods that are of high quality, expensive, and scarce in nature that represent the status of the buyer, and the product may not necessarily be for day-to-day use [17]. In Korean society, the word "luxury" is used to denote a trademark or expensive product rather than a special product and also to represent higher-end foreign brands [18]. The word "luxury" became a representative word of wealth, upper class, and high-end products which is why marketers are intentionally using the term "luxury" with their goods for their marketing activities to fulfill Korean consumers' desires. Luxury goods refer to goods generally recognized by society as 
luxurious and classy goods, both in their exchange value and in their symbolic value. Such luxury goods were previously recognized as being purchased only by the upper class, but now the non-upper class is also actively buying them. The reason why luxury goods are popular is firstly the reproduction of one's possessive desire for high symbolic value goods, and the phenomenon in which the non-upper class is jumping into the buying of luxury goods can also be seen as the desire of "matching"- the act of consuming like others. The desire to show off is the target reason for luxury purchasing, and, in addition, it is possible to buy on the way of falling for the beauty of the luxury brand itself [18]. There is a desire to match the value of one's own value with that of luxury goods-the sense of accomplishment when you put in what you thought would be out of reach. There have been many changes in the shopping behavior of Korean consumers over the past decade. Among them, changes related to the consumption of luxury goods have been very noticeable, and the survey, which was published in 2007 by Anders Consulting, suggests a lot. According to the above-mentioned paper, the perception of value and desire for consumption of luxury goods have become very high among all age groups compared to the past. This could be interpreted by Koreans as luxury goods being no longer expensive products that feel distant but have become part of their lives.

\subsection{Luxury Fashion Goods in Korean University Students}

There has been a rapid increase in the luxury goods market throughout the world. In South Korea, luxury goods consumption continued to grow in 2015 [19]. Among the consumers of these luxury goods, the major consumers were women, which accounted for $60 \%$ of the global luxury market, while men accounted for $40 \%$ [20]. Although the major consumers of luxury goods have traditionally been 40 - to 60 -year-old wealthy women, the demand for luxury goods of younger consumers aged 20-30 years old has sharply increased [21].

Moreover, Park [22] opined that "Korea's luxury goods market has grown more than 10 percent every year since it was imported in earnest with the opening of the retail market in 1996, and it is a major country with 7th to 8th place in the global luxury market." The growth and change of the luxury brand market are accelerating with more opportunities and knowledge of brands than in the past. In other words, consumers' perception of luxury goods in the Korean market can be divided into 1st luxury brand, 2nd class, Young luxury brand, and Masstige luxury brand, and the market segment is expected to accelerate in the future as the market is rapidly growing, and more and more young people and college students are spending on luxury brand names. Young college students watch K-Pop and Korean drama, while popular songs and movies are of relatively high interest, hence the Korean wave influences college students' purchasing behavior toward fashion luxury brands [23]. Thus it is important to look into their purchase behavior and what influences them to invest money in luxury products.

\subsection{Hypothesis Development}

\subsubsection{Brand Awareness}

Brand awareness has been defined as consumers' psychological orientation to choose highly advertised, well-known brand-name products [24,25]. It is the sensitivity to brand names that are psychologically important to consumers before purchasing a product, and as a consumer, an individual wants to value the brand and purchase a famous brand [26]. The brand represents a social level, including the buyer's status and authority. People tend to judge a person by their clothes, accessories, etc. People buy luxury items from famous brands to raise their status. These people prioritize the product's external properties over the properties of the product's durability, practicality, etc. This shows that the more socially motivated consumers are, the more sensitive they are to the brand, and the lower price resistance they have to purchase brand products [27]. Consumers with a high sense of brand are the first to identify a brand when purchasing a product, and the brand has an important influence on their decision making [27]. If these purchases continue, it will increase consumers' preference for 
a particular brand and consumers' loyalty to luxury goods. Therefore, from the above discussion, the following hypothesis was developed:

Hypothesis 1 (H1). Brand awareness is positively related to Korean college students' attitudes toward buying luxury goods.

\subsubsection{Acquisitive}

As individuals traverse from childhood to adolescence, there is an evolution of self-definition from acquiring possessions to engaging in activities related to identity [28]. Consumer's ideal identity and lifestyle are expressed by material goods, which helps some consumers fulfill their sense of self. According to previous research, it has been examined how individuals who are materialistic believe the acquisition of objects will help them establish a sense of security and improve their well-being.

Acquisitive is defined as the importance to which a consumer attaches to attaining worldly possessions $[28,29]$. It is a term referring to the trend of placing importance on economic and material values, thus losing the inherent value of human beings to possess and belittling them, and it is a general phenomenon resulting from the improvement of material conditions in a society where there was a lack of material conditions in life. Possessions become a main focus when materialism (acquisitive) is highly important in one's value system. According to Richins and Dawson [30], materialism has been divided into three aspects, such as: (1) the central focus in his or her life is the acquisition of material possessions, (2) his or her main source of life satisfaction is the pursuit of material possessions, and (3) possessions are viewed as a marker for success.

Acquisitive encourages consumers to be conscious of their status and spend a superfluous amount of their resources on acquiring goods [31,32]. It is very important to understand consumers' materialistic tendencies or behaviors because they, directly and indirectly, affect the causes and consequences of their daily consumption behaviors [33]. It is found that those with a high materialistic incline to show their own success or strengthening their social status and appearance [34]. Furthermore, Ji-Won and Soon-Hee [35] studied the effects of acquisitive on imported luxury goods preferences among college students and found that the higher the acquisitive tendency, the more significant the preference for imported luxury goods is among college students. Thus, the following hypothesis was developed:

Hypothesis 2 (H2). Acquisitive is positively related to Korean college students' attitudes toward buying luxury goods.

\subsubsection{Social Contrast}

Social contrast theory proposes that individuals who want to evaluate themselves compare with others [36] and thus usually evaluate their opinions and abilities by comparing them with the opinions and abilities of other people when objective criteria are not available, and when a discrepancy exists in regard to opinions, people tend to change their own positions to be closer to others in a social group [36]. According to Moschis and Churchill [37], individuals are considered to be more devoted if they regularly interact with peers, and Achenreiner [38] posits that individuals are more easily influenced by others.

It has been indicated that social contrast with friends and social contrast with media figures, normative peer influence, peer communication, and motivation to view advertisements all have positive effects on the attachment to worldly possessions [39]. According to previous research, consumers' emphasis on need or status symbols differs. U.S. consumers give emphasis to their own needs whereas Chinese consumers emphasize status symbols since they put more value on the need to be associated with the group rather than their own needs [40]. Research findings from Kang and Park-Poaps [41] indicated the antecedents and outcomes of social shopping, including social contrast and shopping satisfaction, respectively. Therefore, based on this assumption, the following hypothesis was developed: 
Hypothesis 3 (H3). Social contrasts have a positive effect on the way people buy luxury fashion products.

\subsubsection{Fashion Innovativeness}

Fashion innovativeness is defined as an individual's disposition to purchase new and different items rather than stick with previous choices and consumption patterns [42]. According to Goldsmith, et al. [43], consumers who are the first to adopt new apparel products are considered as fashion innovators. Fashion innovators are among the first buyers of the latest styles and product lines, and reactions toward new styles and product lines may also influence later adopters. Researchers in various fields have conducted studies on the characteristics of innovators to describe and explain how and why this behavior arises and how certain psychological characteristics are associated with it. Furthermore, there has been little or no research on the relationship between fashion innovativeness and luxury fashion consumption. Innovativeness is considered crucial in the areas of marketing and consumer research due to the importance of innovators to new product success [44]. According to the research by Ji-Young and Eun-Ju [45], it was found that there were differences in purchase intention affected by design characteristics in bags, shoes, and accessories category. In addition, based on the research findings, it was suggested to focus on innovative design characteristics for luxury brands and to identify specifically the different needs of consumers through fashion-related behavioral factors. Thus, the following hypothesis was drawn:

Hypothesis 4 (H4). Fashion innovation is positively related to attitudes toward buying luxury goods.

\subsubsection{Engagement in Fashion}

Engagement in fashion can be defined based on the aggregate effect of a variety of important fashion behavioral activities. It is the level of perception or interest in a particular subject in a given situation or the level of personal importance or interest associated with one's own important value in a particular situation in the purchase of a fashion product. Engagement in fashion is presented in fashion research as an important variable that has a lot of impact on consumer behavior. The idea of fashion involvement plays a crucial role in explaining consumer behavior, such as the formation of attitudes [46]. Fashion involvement is a key concept in market segmentation, as highly relevant consumers are generally considered to be concentrated buyers of fashion products [47]. Consumers who are highly involved in fashion have emerged as very influential leaders in the overall fashion adoption process [48-50]. Based on this information, the following hypotheses were developed:

Hypothesis 5 (H5). Engagement in fashion has a strong influence on the purchase of fashion products.

\subsection{Attitude Toward Buying Luxury Product}

Attitude toward buying a luxury product is defined as a subjective possibility that includes the relationship between the person and the purchase behavior and as a variable between the person's attitude to the act of purchase [51]. Attitudes toward the performance of actions are widely accepted as the determinant of intent to perform actions. The reasonable behavioral theory developed by Fishbein and Ajzen [52] suggests that attitudes to behavior are related to behavioral intent. According to Zhang and Kim [53], the purchase intention of luxury products depends on several factors, like psychological preference toward brand name and brand consciousness. Extensive research has supported positive predictions of attitudes toward purchasing intentions [54,55]. Research done by Zhang, et al. [56] mentioned that experience of purchasing luxury products earlier will have a direct impact on consumer purchase intention. In the context of luxury consumption, previous research found a positive relationship between consumers' attitudes toward luxury brands and their willingness to buy luxury brands. Thus, the following hypothesis was developed: 
Hypothesis 6 (H6). The attitude toward buying luxury goods is related to the intention of purchasing luxury goods.

\section{Research Method}

\subsection{Data Collection and Its Process}

The data were collected from college students who were studying at different universities in South Korea. Both online and paper-based questionnaires were used to collect data to test our proposed model given in Figure 1. For online data collection, Google Form (https://www.google.com/forms/about/) was used to disseminate the survey. Google Forms is a widely used survey administration app which is a part of the Google Drive office suite, along with Google Docs, Google Sheets, and Google Slides. Its features are the same as in other Google Drive apps such as collaboration and sharing features which are found in Docs, Sheets, and Slides. The questionnaire of the study was divided into three sections. The initial part of this survey was about consent, followed by the item questions to measure each variable, such as brand awareness, acquisitive social contrast, innovation in fashion, engagement in fashion, attitude toward buying luxury products, and buying intention of luxury products. The final section of this questionnaire included demographic information such as fashion goods, buying experience of luxury goods, gender, age, and acquisitive status.

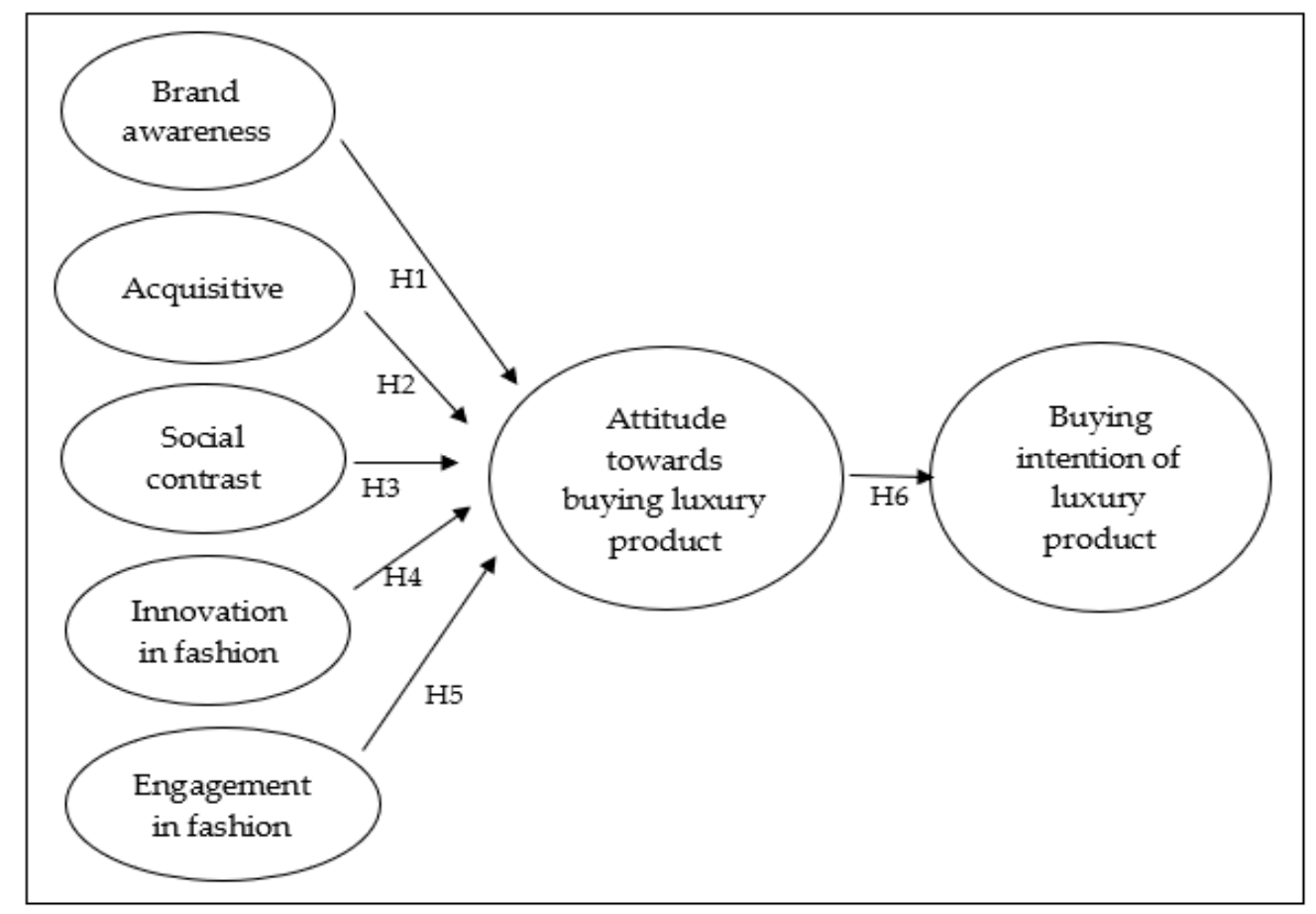

Figure 1. Proposed model.

The item questions of the survey were originally written in English; however, it has been translated into the Korean language for a better understanding of the local students. A bilingual Korean professor was asked to check the accuracy of the translation. Based on his opinion, the questionnaire was modified slightly to ensure clarity and understanding. As the data were mostly collected through an online portal, consent was taken from the participant while filling out the form.

\subsection{Instruments}

Most of the question items were taken from previous papers and were slightly modified as per the research requirement. Detailed information about the instrument is given billow in Table 1. 
Table 1. Authors and scale development.

\begin{tabular}{|c|c|c|c|}
\hline Variables & Authors & $\begin{array}{c}\text { No. of Items } \\
(1=\text { Strongly Disagree to } \\
7=\text { Strongly Agree })\end{array}$ & Likert Scales \\
\hline Brand awareness & Sproles and Kendall (1986) & 7 & 7 \\
\hline Brand awareness & Tai and Tam (1997) & 3 & 7 \\
\hline Acquisitive & $\begin{array}{l}\text { Wong et al. (2003), Richins and } \\
\text { Dawson's (1992), and Richins (2004) }\end{array}$ & 15 & 7 \\
\hline Innovation in fashion & Goldsmith and Hofacker (1991) & 6 & 7 \\
\hline Social Contrast & Chan and Prendergast's (2007) & 4 & 7 \\
\hline Engagement in Fashion & Chae et al. (2006) & 15 & 7 \\
\hline Buying Intention & Summers et al. (2006) & 2 & 7 \\
\hline $\begin{array}{l}\text { Attitude towards buying } \\
\text { luxury product }\end{array}$ & $\begin{array}{l}\text { Park et al. (2007) and } \\
\text { Zhang B. et al. (2013) }\end{array}$ & 4 & 7 \\
\hline
\end{tabular}

A total of 56 question items were adopted from earlier research papers to fulfill our research measurement. These items were marked by a recursive scale at an even point, and the range varied as well, except for items on the attitude of purchasing goods; seven-point recursions were used, while those on the attitude of buying luxury goods used a five-point Likert scale.

\section{Results}

\subsection{Sample}

A total of 200 questionnaires were distributed online as well as paper-based, however only 176 respondents filled up and returned our questionnaire. Twenty-three samples were eliminated due to missing and inappropriate answers. Therefore, a total of 153 respondents were selected for this research, with about $53 \%(n=82)$ of the respondents being women, and about $47 \%(n=71)$ being men. Those aged 23 or older accounted for $41.2 \%$ of the respondents, followed by those aged 22, 21, and 20 . None of the participants were under the age of 20 . The respondents' monthly allowance ranged from less than 300,000 won to more than 600,000 won, with about $34.7 \%$ receiving between 300,000 and 399,999 won ( 1 euro $=1400$ won). About $55.6 \%$ of respondents did not buy luxury goods in the past six months, while $75.2 \%$ of respondents spent between 150,000 won and 499.999 won per item. Table 2 provides a detailed description of the respondent profile.

Table 2. Profiles and the respondents.

\begin{tabular}{ccc}
\hline Measure & Items & Percentage \\
\hline Gender & Male & 47 \\
& Female & 53 \\
Age & 20 & 17.6 \\
& 21 & 22.9 \\
& 22 & 18.3 \\
Education & 23 or older & 41.2 \\
Monthly income in won & University students & 100 \\
& Under 300,000 & 26.1 \\
& $300,000-399,999$ & 34.7 \\
& $400,000-499,999$ & 24.8 \\
& $500,000-599,999$ & 5.2 \\
& 600,000 and over & 10.5 \\
\hline
\end{tabular}


Table 2. Cont.

\begin{tabular}{ccc}
\hline Measure & Items & Percentage \\
\hline Amount of luxury fashion goods & No items & 55.6 \\
purchased within the last 6 months & $1-3$ items & 30.7 \\
& $4-6$ items or more & 13.7 \\
Money spent on one luxury & $150,000-499,999$ won & 75.2 \\
fashion item & $500,000-799,999$ won & 16.3 \\
& $800,000-999,999$ won & 5.2 \\
& $1,000,000-1499,999$ won & 1.3 \\
& $1,500,000-4999,999$ won & 2.0 \\
\hline
\end{tabular}

\subsection{Confirmatory Factor Analysis (CFA)}

To check the validity of the research model, Confirmatory Factor Analysis was performed using SPSS statistical software. CFA is a factorial analysis method for verifying the validity of a design, hypothesis, or postulated factorial structure. Model fit is normally evaluated with five different fitness indexes: chi-square statistics, non-standard fitment index (NNFI), comparison fit index (CFI), incremental fitment index (IFI), and root mean square error of approximation (RMSEA), and we analyzed the CFA factors using SPSS. Based on the data values obtained using forms, the validity and reliability of the data values were reviewed by using SPSS to identify factor loading, Cronbach's alpha value (Cronbach's $\alpha$ ), and mean and standard deviation values. Table 3 illustrates factor loading and $t$-value as well as Average Variance Extracted(AVE). The reliability measurement coefficient, Cronbach's alpha value, was then used to determine if it was suitable for the use of the analysis. Table 4 provides the means, standard deviations, and correlations within the independent variables.

Table 3. Confirmatory factor loading and $t$-value.

\begin{tabular}{|c|c|c|c|}
\hline Factors and Items & \multicolumn{2}{|l|}{ Factor Loading } & $t$-Value \\
\hline \multicolumn{4}{|c|}{ Brand awareness $(\alpha=0.84 ; A V E=0.72 ; C R=0.89)$} \\
\hline 4. & $\begin{array}{l}\text { High-end specialty stores and department stores } \\
\text { offer me the best products }\end{array}$ & 0.770 & - \\
\hline 3. & $\begin{array}{l}\text { The higher the price of a product, } \\
\text { the better its quality }\end{array}$ & 0.874 & 9.82 \\
\hline 5. & I prefer to buy the best-selling brand products & 0.843 & 7.04 \\
\hline 6. & $\begin{array}{c}\text { The most advertised brand product is } \\
\text { usually a good choice }\end{array}$ & 0.756 & 5.59 \\
\hline 8. & I am willing to pay a high price for a famous brand & 0.699 & 8.10 \\
\hline 10. & I prefer buying foreign brands to domestic brands & 0.815 & 6.03 \\
\hline \multicolumn{4}{|c|}{ Acquisitive $(\alpha=0.81 ; A V E=0.61 ; C R=0.88)$} \\
\hline 1. & $\begin{array}{c}\text { How do you feel about people who own expensive } \\
\text { homes, car and clothes? } \\
\text { (Do not admire-greatly admire) }\end{array}$ & 0.681 & - \\
\hline 4. & $\begin{array}{l}\text { How do you feel about acquiring material } \\
\text { possessions as an achievement in life? } \\
\text { (Not important-vary important) }\end{array}$ & 0.821 & 6.64 \\
\hline 6. & $\begin{array}{l}\text { Would your life be any better if you owned certain } \\
\text { things that you do not have now? (Not any } \\
\text { better-much better) }\end{array}$ & 0.766 & 4.38 \\
\hline 8. & $\begin{array}{l}\text { How would you feel if you could afford to buy } \\
\text { more things? (Not any happier-much happier) }\end{array}$ & 0.883 & 8.07 \\
\hline 9. & $\begin{array}{l}\text { How would you feel if you } \\
\text { owned something better? }\end{array}$ & 0.768 & 3.99 \\
\hline 15. & $\begin{array}{l}\text { What do you think about living } \\
\text { a lot of luxurious life? }\end{array}$ & 0.688 & 5.02 \\
\hline
\end{tabular}


Table 3. Cont.

\begin{tabular}{|c|c|c|c|}
\hline Factors and Items & \multicolumn{2}{|l|}{ Factor Loading } & $t$-Value \\
\hline \multicolumn{4}{|c|}{ Social Contrast ( $\alpha=0.79 ; A V E=0.71 ; C R=0.81)$} \\
\hline 1. & $\begin{array}{l}\text { I am interested in which brand my favorite } \\
\text { entertainer is using. }\end{array}$ & 0.790 & - \\
\hline 2. & $\begin{array}{l}\text { I pay importance to my rich friends' and watch } \\
\text { what they buy. }\end{array}$ & 0.829 & 6.49 \\
\hline 3. & $\begin{array}{l}\text { I give importance to what brands my favorite } \\
\text { movie stars and pop singers are using. }\end{array}$ & 0.910 & 7.05 \\
\hline \multicolumn{4}{|c|}{ Innovation in fashion ( $\alpha=0.83 ; A V E=0.69 ; C R=0.84)$} \\
\hline 1. & $\begin{array}{l}\text { Normally, I am the last in my circle of friends to } \\
\text { know the names of the latest new fashions }\end{array}$ & 0.743 & - \\
\hline 2. & $\begin{array}{l}\text { In general, I am among the last in my circle of } \\
\text { friends to buy a new fashion item when it appears. }\end{array}$ & 0.841 & 8.60 \\
\hline 3. & $\begin{array}{l}\text { Compared to my friends, } \\
\text { I own few new fashion items. }\end{array}$ & 0.796 & 7.06 \\
\hline \multicolumn{4}{|c|}{ Engagement in fashion $(\alpha=0.85 ; A V E=0.77 ; C R=0.91)$} \\
\hline 1. & Fashion goods matter to me. & 0.877 & - \\
\hline 3. & My friends turn to me for advice on fashion goods. & 0.707 & 11.03 \\
\hline 4. & $\begin{array}{l}\text { I usually have one or more of the very latest style } \\
\text { fashion goods. }\end{array}$ & 0.812 & 8.89 \\
\hline 5. & I like to shop for fashion goods. & 0.719 & 10.18 \\
\hline 6. & I usually dress for fashion not comfort. & 0.898 & 6.62 \\
\hline 7. & I think I am sensitive to fashion. & 0.822 & 7.66 \\
\hline 13. & $\begin{array}{l}\text { I spend a lot of time trying to find the fashion } \\
\text { products I want. }\end{array}$ & 0.726 & 9.35 \\
\hline
\end{tabular}

Table 4. Means, standard deviations, and correlations.

\begin{tabular}{lcccccccc}
\hline & & Mean & Std. Dev. & $\mathbf{1}$ & $\mathbf{2}$ & $\mathbf{3}$ & $\mathbf{4}$ & $\mathbf{5}$ \\
\hline 1 & Brand awareness & 4.13 & 1.18 & 1 & & & & \\
2 & Acquisitive & 3.99 & 1.20 & 0.41 & 1 & & & \\
3 & Social contrast & 2.87 & 1.32 & 0.23 & 0.17 & 1 & & \\
4 & Innovation in fashion & 4.36 & 1.26 & 0.25 & 0.26 & 0.17 & 1 & \\
5 & Engagement in fashion & 3.81 & 1.55 & 0.32 & 0.21 & 0.29 & 0.44 & 1 \\
\hline
\end{tabular}

\subsection{Testing Hypotheses}

According to Lei and $\mathrm{Wu}$ [57], the model estimate does not work well with SEM when the sample size is small. Thus, regression analysis was performed to test hypotheses over SEM. Item questions of each dimension were added and averaged using SPSS to represent that dimension. A higher value denotes a higher degree of each variable. A 0.05 level was set to check statistical significance. To test hypotheses starting from 1 to 5 , brand awareness, acquisitive, social contrast, innovation in fashion, and engagement in fashion were used as independent variables whereas attitude toward buying luxury fashion products was used as an independent variable. The regression table (Table 5) shows the independent variable explain $27 \%$ of the variance in attitude toward buying luxury fashion product.

Regression results in Table 5 revealed that brand awareness $\beta=0.36, p<0.01$, social contrast $\beta=0.14, p<0.03$, and innovation in fashion $\beta=0.39$, and $p<0.001$ is significantly related to attitude toward buying luxury products. Thus, hypotheses 1,3 , and 4 were supported. 
Table 5. Regression results.

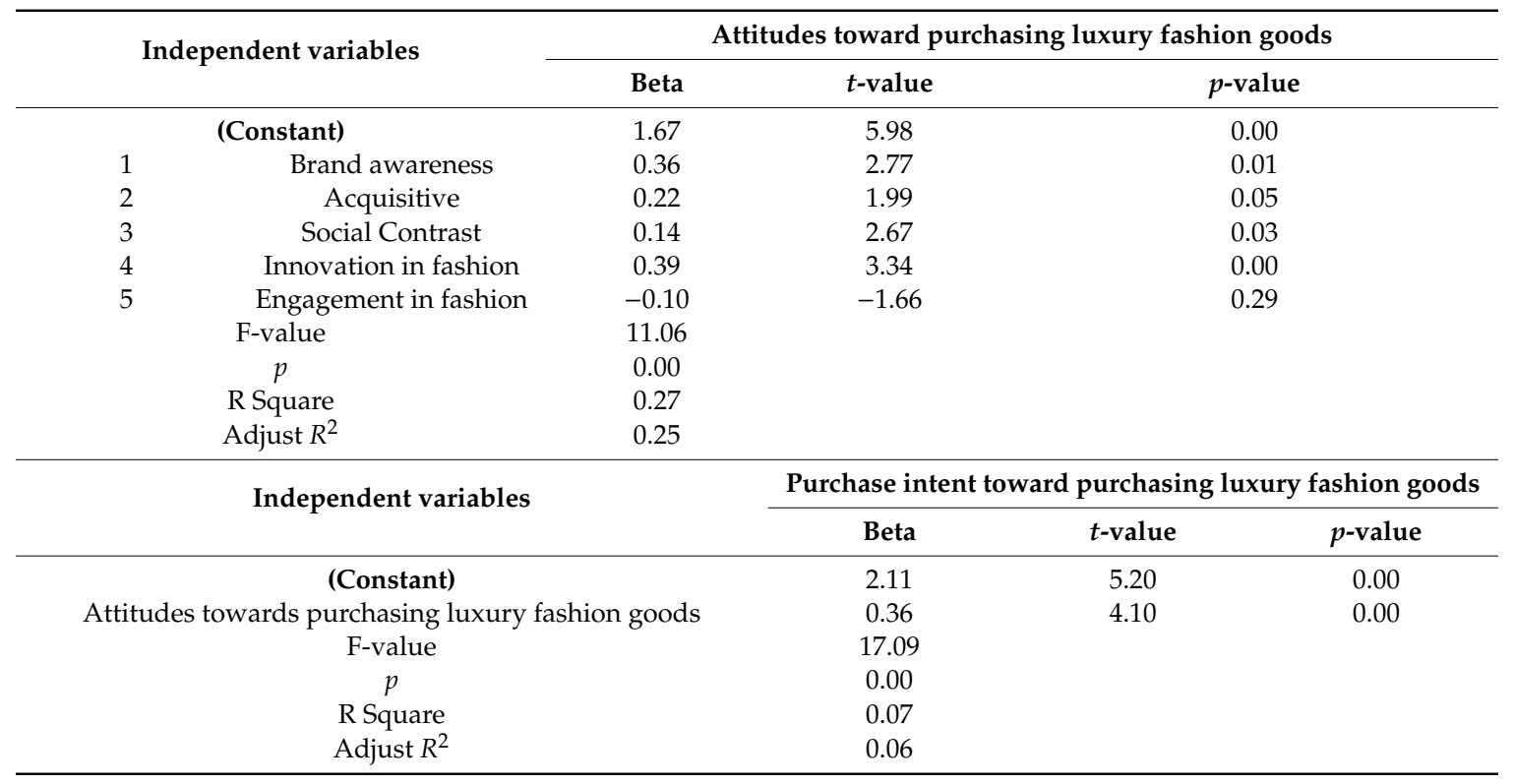

\subsection{Testing Hypotheses}

Structure equation modeling (SEM) was intended to be used to test conceptual models and research hypotheses, however, due to the sensitivity of the sample size, SEM was considered to be not suitable for this research. According to Lei and Wu [57], the model estimate does not work well with SEM when the sample size is small. Thus, regression analysis was performed to test hypotheses over SEM. Item questions of each dimension were added and averaged using SPSS to represent that dimension. A higher value denotes a higher degree of each variable. A 0.05 level was set to check statistical significance. To test hypotheses starting from 1 to 5 , brand awareness, acquisitive, social contrast, innovation in fashion, and engagement in fashion were used as independent variables whereas attitude toward buying luxury fashion products was used as an independent variable. The regression table (Table 5) shows the independent variable explain $27 \%$ of the variance in attitude toward buying luxury fashion product. Regression results in Table 5 revealed that brand awareness, $\beta=0.36, p<0.01$, social contrast, $\beta=0.14, p<0.03$, and innovation in fashion, $\beta=0.39, p<0.001$, are significantly related to attitude toward buying luxury products. Thus, hypotheses 1,3 , and 4 were supported.

Therefore, to test the hypotheses, a measure item of each dimension was added and averaged using the SPSS to represent that dimension. Brand awareness, acquisitive, social contrast, innovation in fashion, and engagement in fashion were used as independent variables and as dependent variables in purchasing luxury goods to test hypotheses 1 to 5 by obtaining average and standard deviation for each survey item. Table 4 shows these results and the average level of the answer when it is set as the reference point from 1 to 7 , which was not deemed to have much to do with attitudes and perceptions of buying luxury goods.

\section{Discussion and Conclusions}

One of the main objectives of this study was to identify the influencing factors that affect young Korean college students' attitudes toward purchasing luxury fashion products. Going through the data and the trend, it was interesting to learn and discover the new emerging luxury market in Korea, after China, Asia's largest luxury market. In the past, people in their 30s and 40s, whose income was relatively high, used to be the main consumers, but recently, people in their 20s showed increased interest in fashion or luxury goods, self-efficiency, and social comparative pursuit. The results of this research showed that brand awareness is one of the important variables in assessing Korean college students' attitudes toward buying luxury products. The findings showed the frequency of shopping 
for general fashion goods was higher than "normal." This may be associated with the social status and reputation an individual perceived when buying luxury products. In Korean society, people have luxury products to assert their wealth and choose to buy luxury products to denote their prestige and status.

On the other hand, social contrast and attitude toward buying luxury products showed a significant relationship. Korean students pay attention to their peers dressing and the items they possess. They also follow K-Pop, look into their dressing sense, and always copy their latest fashion. As Korean college students broadly imitate K-Pop singers trends and the brands they follow, marketers used to sponsor popular K-Pop singers to promote their product and increase brand value. Besides friends, students also tend to follow those whom they admire. Apart from brand awareness and social contrast, innovation in fashion was also found to be important for Koran college students. As they are college students and academically sound, they are conscious of brand value. Therefore, retail companies should pay more attention to come up with new innovative product frequently to keep the customer who loves innovative fashion products. Earlier research stated that consumer purchase behavior is influenced by peers [58], and the current study validates that Korean students are also influenced by their peers. The result of this study could help fashion brand manufacturers to strategize their marketing methods to capture more young customers and may use young influencers (K-Pop singers) to promote their products which can help to grab more young customers.

In our research, acquisitive showed a marginal significance with the attitude toward buying luxury products. An earlier research paper by Juan Li and Su [59] explained that acquisitiveness itself cannot be a significant factor when it comes to a collective society. People in a collective society tend to have a high level of acquisitive than in western culture. Thus, the firm targeting the Korean luxury market segment should clearly understand Korean culture and society. The Korean students who quickly convert to the luxury products consumption group are aged between 20 and 30 years. Thus, the finding of this research postulated the important factors that affect the luxury product consumption, and the targeted age group could be college students for a profitable business. The result of this study could also be valuable for strategy building for the marketer who is producing luxury products for the young age group. This research also suggested that a marketing manager or marketing strategy builder should emphasize presenting luxury products as symbols of wealth and beauty to young Korean customers, which will boost social pressure. Apart from this, the marketing manager should also need to concentrate on the proliferation of the brand symbol. This research could give us a sense that popular Korean K-Pop singers could influence prospective buyers as they are popular around the world and very trendy as well as fashionable, young, and beautiful. Thus future studies could be done to explore the moderating role of K-Pop/Korean drama in brand selection or the purchase intention of branded products by the young generation. Besides this, the present paper included a few variables; there could be other variables which might extend and give comprehensive results of the factors of purchase intention. Korea is a homogenous society and carries a similar and strong national culture. Thus, buying foreign luxury brands may be influenced by local sentiments. Further study can look into the local sentiments of purchasing luxury foreign brands. Therefore, a qualitative or mixed-methods approach could be proposed to better understand the attitudes of young people toward luxury brands.

Like many other papers, this paper also has several limitations. The sample for this research was only taken from a few universities, thus it would be difficult to generalize the result of this study. Collecting samples from several universities from several geographical regions could have given a more comprehensive understanding of the research. Besides this, the sample size is comparatively low. Increasing sample size may increase the generalizability of the finding. Future research can be done by adding a larger sample size from nationwide. Finally, there was a high number of questions in our questionnaire, which could lead to survey fatigue. A more concise questionnaire could increase the number of respondents as well as the quality of the research results. 
Author Contributions: Conceptualization, M.I.; methodology, M.I.; software B.N.S.; validation, M.I., and B.N.S.; formal analysis, M.I.; investigation, M.I.; resources, B.N.S.; data curation, M.I., B.N.S.; writing-original draft preparation, M.I.; writing-review and editing, B.N.S.; visualization, B.N.S. All authors have read and agreed to the published version of the manuscript.

Funding: The research received no external funding.

Conflicts of Interest: The authors declare no conflict of interest.

\section{References}

1. Kleiner, J.R. Korea, a Century of Change; World Scientific: Singapore, 2001; Volume 6.

2. Junkyu, L. Korea's Trade Structure and Its Policy Challenges; The Future of Korean Trade Policy; Korea Economic Institute of America: Washington, DC, USA, 2012; Volume 28.

3. The Great Changes in Korean Lifestyle. Available online: https://www.lgad.co.kr/webzine/030102/study/ study3.htm (accessed on 3 February 2020).

4. Kirk, D. Central Bank Chides Koreans for Their Spendthrift Ways. Available online: https://www. nytimes.com/2002/10/04/business/central-bank-chides-koreans-for-their-spendthrift-ways.html (accessed on 4 August 2020).

5. Kweon, Y.H.K.S.A.; Kim, E.J.; Han, A.R. Recognition and Purchasing Attitude toward Fashion Luxury Brand by University Students in Cheongju. 충북대학교 생활과학연구소 2007, 10, 275-288.

6. Koh, I.K. An Exploratory Study on Korean 20's Consuming Behaviors in Luxuries and Imitations. Asia-Pac. J. Bus. Ventur. Entrep. 2014, 10, 77-84.

7. Altagamma 2014 Worldwide Markets Monitor. Available online: http://www.luxesf.com/wp-content/ uploads/2014/11/Altagama-Monitor1.pdf (accessed on 5 March 2020).

8. Lens on the Worldwide Luxury Consumer. Available online: https://recursos.anuncios.com/files/598/20.pdf (accessed on 5 March 2020).

9. Kim, A.J.; Ko, E. Do social media marketing activities enhance customer equity? An empirical study of luxury fashion brand. J. Bus. Res. 2012, 65, 1480-1486. [CrossRef]

10. Larraufie, A.-F.M.; Kourdoughli, A. The e-semiotics of luxury. J. Glob. Fash. Mark. 2014, 5, 197-208. [CrossRef]

11. Mortelmans, D. Sign values in processes of distinction: The concept of luxury. Semiotica 2005, 2005, 497-520. [CrossRef]

12. Cristini, H.; Kauppinen-Räisänen, H.; Barthod-Prothade, M.; Woodside, A. Toward a general theory of luxury: Advancing from workbench definitions and theoretical transformations. J. Bus. Res. 2017, 70, 101-107. [CrossRef]

13. Miller, K.W.; Mills, M.K. Contributing clarity by examining brand luxury in the fashion market. J. Bus. Res. 2012, 65, 1471-1479. [CrossRef]

14. Berthon, P.; Pitt, L.; Parent, M.; Berthon, J.-P. Aesthetics and ephemerality: Observing and preserving the luxury brand. Calif. Manag. Rev. 2009, 52, 45-66. [CrossRef]

15. Godey, B.; Pederzoli, D.; Aiello, G.; Donvito, R.; Chan, P.; Oh, H.; Singh, R.; Skorobogatykh, I.I.; Tsuchiya, J.; Weitz, B. Brand and country-of-origin effect on consumers' decision to purchase luxury products. J. Bus. Res. 2012, 65, 1461-1470. [CrossRef]

16. Michel, C.; Gerald, M. Luxury Brand Management; Original work published 2008; Son, J.Y., Translator; Miraebook Publishing: Seoul, Korea, 2008.

17. Zhang, L.; Cude, B.J. Chinese consumers' purchase intentions for luxury clothing: A comparison between luxury consumers and non-luxury consumers. J. Int. Consum. Mark. 2018, 30, 336-349. [CrossRef]

18. Kim, Y. Social Foundation of Luxury Good Obsession in South Korea; Brandeis University: Waltham, MA, USA, 2011.

19. International, E. Luxury Goods in South Korea. Available online: http://www.euromonitor.com/luxurygoods-in-south-korea/report (accessed on 4 August 2020).

20. Company, B. 2013 Luxury Goods Worldwide Market Study. Available online: http://recursos.anuncios.com/ files/581/60.pdf (accessed on 6 August 2020).

21. Choi, E.-J.; Hong, K.-H.; Lee, Y.-J. Korean consumers' perceptions toward luxury products. J. Fash. Bus. 2010, 14, 195-215. 
22. Park, J.A. Transactions: A Study on Korean and Japanese Consumers' Attitudes and Consumer Knowledge about Luxury Brands. J. Korean Soc. Cloth. Text. 2010, 34, 1303-1318. [CrossRef]

23. Hong, K.-H.; Liu, J. Korean fashion brand purchasing behavior by fashion leadership and Korean wave of college women students in China. J. Korean Soc. Cloth. Text. 2009, 33, 655-665. [CrossRef]

24. Shim, S.; Gehrt, K.C. Hispanic and Native American adolescents: An exploratory study of their approach to shopping. J. Retail. 1996, 72, 307-324. [CrossRef]

25. Sprotles, G.B.; Kendall, E.L. A methodology for profiling consumers' decision-making styles. J. Consum. Aff. 1986, 20, 267-279. [CrossRef]

26. SungHawe, H.; Hyun, H.D. Structural Relationships among Brand Consciousness, Happiness, Brand Identification and Brand Loyalty: Focused on In-bound Chinese Tourists. Korea Assoc. Bus. Educ. 2017, 32, 375-395. [CrossRef]

27. Park, J.; Lee, K. Male emerging adults' self-perceived superiority and clothing values: The influences on brand conciousness and brand loyalty behavior. J. Brand Des. Assoc. Korea 2013, 26, 225-236. [CrossRef]

28. Belk, R.W. Materialism: Trait aspects of living in the material world. J. Consum. Res. 1985, 12, $265-280$. [CrossRef]

29. Richins, M.L. When wanting is better than having: Materialism, transformation expectations, and product-evoked emotions in the purchase process. J. Consum. Res. 2012, 40,1-18. [CrossRef]

30. Richins, M.L.; Dawson, S. A consumer values orientation for materialism and its measurement: Scale development and validation. J. Consum. Res. 1992, 19, 303-316. [CrossRef]

31. Goldsmith, R.E.; Clark, R.A. Materialism, status consumption, and consumer independence. J. Soc. Psychol. 2012, 152, 43-60. [CrossRef]

32. Silvera, D.H.; Lavack, A.M.; Kropp, F. Impulse buying: The role of affect, social influence, and subjective wellbeing. J. Consum. Mark. 2008, 25, 23-33. [CrossRef]

33. Kim, J.H. The Impact of Materialism on Impulse Buying and Happiness after Shopping. Korea Logist. Res. Assoc. 2017, 27, 181-192. [CrossRef]

34. Richins, M.L. Special possessions and the expression of material values. J. Consum. Res. 1994, 21, $522-533$. [CrossRef]

35. Ji-Won, J.; Soon-Hee, J.; Wook, C.K. Materialism, Conspicuous Consumption, and Preference for Imported Luxury Brands Among College Students. J. Korean Home Manag. Assoc. 2003, 21, 181-192.

36. Festinger, L. A theory of social comparison processes. Hum. Relat. 1954, 7, 117-140. [CrossRef]

37. Moschis, G.P.; Churchill, G.A. Consumer Socialization: A Theoretical and Empirical Analysis. J. Mark. Res. 1978, 15, 599-609. [CrossRef]

38. Achenreiner, G.B. Materialistic Values and Susceptibility to Influence in Children. Adv. Consum. Res. 1997, 24, 82-88.

39. Chan, K.; Prendergast, G. Materialism and social comparison among adolescents. Soc. Behav. Personal. Int. J. 2007, 35, 213-228. [CrossRef]

40. Adams, R. The utility of prestige: Chinese and American hedonic ratings of prestige goods. J. Glob. Mark. 2011, 24, 287-304. [CrossRef]

41. Kang, J.; Park-Poaps, H. Motivational Antecedents of Social Shopping for Fashion and its Contribution to Shopping Satisfaction. Cloth. Text. Res. J. 2011, 29, 331-347. [CrossRef]

42. Im, S.; Bayus, B.L.; Mason, C.H. An empirical study of innate consumer innovativeness, personal characteristics, and new-product adoption behavior. J. Acad. Mark. Sci. 2003, 31, 61-73. [CrossRef]

43. Goldsmith, R.E.; Freiden, J.B.; Kilsheimer, J.C. Social values and female fashion leadership: A cross-cultural study. Psychol. Mark. 1993, 10,399-412. [CrossRef]

44. Foxall, G.R.; Bhate, S. Cognitive styles and personal involvement of market initiators for 'healthy'food brands: Implications for adoption theory. J. Econ. Psychol. 1993, 14, 33-56. [CrossRef]

45. Ji-Young, K.A.; Eun-Ju, K. The Impact of Design Characteristics on Brand Attitude and Purchase Intention-Focus on Luxury Fashion Brands. J. Korean Soc. Cloth. Text. 2010, 34, 252-265. [CrossRef]

46. Summers, T.A.; Belleau, B.D.; Xu, Y. Predicting purchase intention of a controversial luxury apparel product. J. Fash. Mark. Manag. Int. J. 2006, 10, 405-419. [CrossRef]

47. Hong, K.-H.; Rucker, M. The role of product type and consumer fashion involvement in clothing satisfaction. J. Consum. Satisf. Dissatisfaction Complain. Behav. 1995, 8, 198-207. 
48. Goldsmith, R.E.; Hofacker, C.F. Measuring consumer innovativeness. J. Acad. Mark. Sci. 1991, 19, $209-221$. [CrossRef]

49. Tigert, D.J.; Ring, L.J.; King, C.W. Fashion involvement and buying behavior: A methodological study. ACR N. Am. Adv. 1976, 3, 46-52.

50. Naderi, I. Beyond the fad: A critical review of consumer fashion involvement. Int. J. Consum. Stud. 2013, 37, 84-104. [CrossRef]

51. Fishbein, M.; Ajzen, I. Belief, attitude, intention, and behavior: An introduction to theory and research. J. Bus. Ventur. 1997, 5, 177-189.

52. Fishbein, M.; Ajzen, I. Understanding Attitudes and Predicting Social Behavior; Prentice-hall: Englewood Cliffs, NJ, USA, 1980; Volume 278.

53. Zhang, B.; Kim, J.-H. Luxury fashion consumption in China: Factors affecting attitude and purchase intent. J. Retail. Consum. Serv. 2013, 20,68-79. [CrossRef]

54. Bellman, L.M.; Teich, I.; Clark, S.D. Fashion accessory buying intentions among female millennials. Rev. Bus. 2009, 30, 46-57.

55. Yoh, E.; Damhorst, M.L.; Sapp, S.; Laczniak, R. Consumer adoption of the Internet: The case of apparel shopping. Psychol. Mark. 2003, 20, 1095-1118. [CrossRef]

56. Zhang, L.; Cude, B.J.; Zhao, H. Determinants of Chinese consumers' purchase intentions for luxury goods. Int. J. Mark. Res. 2020, 62, 369-385. [CrossRef]

57. Lei, P.W.; Wu, Q. Introduction to structural equation modeling: Issues and practical considerations. Educ. Meas. Issues Pract. 2007, 26, 33-43. [CrossRef]

58. Ünal, S.; Deniz, E.; Akın, N. Determining the Factors That Influence the Intention to Purchase Luxury Fashion Brands of Young Consumers. Ege Akad. Bakış Derg. 2019, 19, 221-236.

59. Li, J.J.; Su, C. How Face Influences Consumption-A Comparative Study of American and Chinese Consumers. Int. J. Mark. Res. 2007, 49, 237-256.

(C) 2020 by the authors. Licensee MDPI, Basel, Switzerland. This article is an open access article distributed under the terms and conditions of the Creative Commons Attribution (CC BY) license (http://creativecommons.org/licenses/by/4.0/). 